\title{
The ventilation of operating-theatres
}

\author{
By O. M. LIDWELL AND R. E. O. WILLIAMS* \\ Air Hygiene Laboratory, Central Public Health Laboratory, \\ Colindale, London, N.W. 9
}

(Received 14 July 1960)

There have in recent years been numbers of reports showing that where operatingtheatres are ventilated by means of exhaust fans contaminated air from the rest of the hospital may be sucked into them and that this may lead to wound infection. This hazard can be obviated by arranging the ventilating system so as to produce a positive air-pressure in the theatre. However, bacteria are also liberated into the air inside the operating-theatre itself and it is one of the functions of the ventilating system to remove these as rapidly as possible and to minimize the risk that a clean wound may become infected by them. The studies reported here were carried out in order to explore the behaviour of a variety of ventilating installations under working conditions and to determine as far as possible those ventilating arrangements most likely to reduce airborne contamination of the wound to a minimum.

\section{METHODS}

The detailed patterns of air movement in any room are complex and in order to obtain comparable data from different places in a manageable form it was necessary to decide on a standard set of measurements which could be carried out in a reasonable time. On grounds of convenience and accuracy it was decided to use a gaseous tracer substance as an artificially introduced contaminant.

The experiments were carried out with the ventilating conditions approximating as closely as possible to those obtaining during an operation and were often done immediately after an operating session. Apart, however, from some activity by nurses engaged in small jobs about the theatre only the investigators were present in the theatres during the measurements.

The gas used was nitrous oxide. The concentration of this gas present in an air sample can be determined almost instantaneously by its infra-red absorption and commercial apparatus is available which enables a continuous record to be obtained with a full scale sensitivity of 100 parts per million or less.

The gas was liberated in measured amounts and a continuous sample taken from just above the centre of the operating table, which was placed at its normal position in the theatre. The operating-lamp was alight throughout each experiment.

The gas was liberated through controlling jets each placed in the centre of a small perforated spherical plastic shell which was packed with cotton-wool to

* Present address: Department of Bacteriology, Wright-Fleming Institute, St Mary's Hospital Medical School, London, W.2. 
eliminate any directional effect of the gas issuing from the jet. The standard positions and number of the liberating points used were:

(1) Four, approximately at the corners of a square, each being $5 \mathrm{ft}$. above the floor and $4 \mathrm{ft}$. from the sampling point, which was about $3 \mathrm{ft}$. above the floor (Fig. $1 a$ ).

(2) Four similarly disposed, $3 \mathrm{ft}$. above the floor and $2 \mathrm{ft}$. from the sampling point (Fig. $1 b$ ).

(3) Four similarly disposed, $1 \mathrm{ft}$. 6 in. above the floor and $4 \mathrm{ft}$. from the sampling point (Fig. $1 a$ ).

(4) Four, placed at that side of the room where it was judged most activity would take place: the spheres were $1 \mathrm{ft} .6 \mathrm{in}$., $3 \mathrm{ft}$., $4 \mathrm{ft} .6$ in. and $6 \mathrm{ft}$. above the floor.

(5) In some twin suites a single liberating point was used at a central position in the other theatre of the suite.

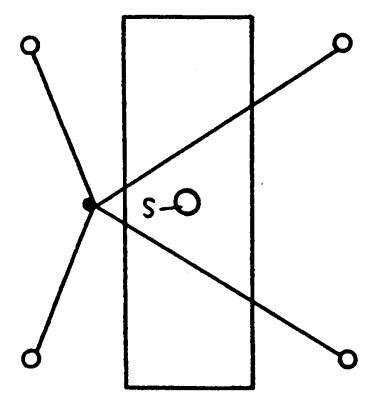

(a)

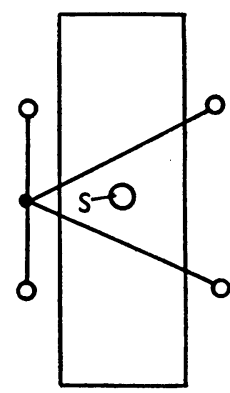

(b)

Fig. 1. Arrangement of jets for liberating the tracer gas. Plans of the positions, in relation to the operating-table, of the jets from which the nitrous oxide was liberated. The perforated spheres containing the jets were carried at the ends of adjustable metal tubes supported from a stand placed to one side of the centre of the table. $S$ represents the sampling point which was a few inches above the top of the table. (a) Position for liberation of the tracer at $5 \mathrm{ft}$. or at $1 \mathrm{ft} .6 \mathrm{in}$. above the floor. (b) Position for liberation of the tracer at $3 \mathrm{ft}$. above the floor.

The first three of these were chosen to represent contamination produced from the head, hands and forearms, and under the gowns of the operating team. The fourth simulates contamination from nurses moving on the periphery of the theatre and the fifth the risk of transfer of contamination from one theatre to another in a twin suite.

The liberation of the gas in any one experiment was normally continued over a period of $3 \mathrm{~min}$. in order to obtain an average effect of the air movements over this period. The use of four orifices disposed around the sampling point was designed to reduce the risk of unrepresentative results due to any systematic drift of the air in a particular direction over the table.

We have used as our principal measure of the effectiveness of the ventilation a quantity referred to as 'the exposure to contamination' (Lidwell, 1960). This has been computed as the integrated product of time and tracer concentration in the sample and is expressed throughout in parts per million $\times$ minutes per litre of 
nitrous oxide liberated. The integration was simply achieved in practice by collecting the air sample, at a constant rate, into a rubber bag and then estimating the concentration in the air collected in the bag. The collection was carried out from the moment at which liberation of the tracer gas began for some suitable period, usually $10 \mathrm{~min}$. If the concentration in the air in the bag were $\bar{c}$ parts per million of nitrous oxide and the total sampling time were $t$ minutes then the exposure to contamination over the sampling period would be $\bar{c} t$ parts per million $\times$ minutes.

In order to evaluate the total exposure to contamination, it is necessary to allow for any residual gas left from the previous experiment and for the tracer gas still present at the end of the sampling period. By suitably arranging the experiments these amounts can be made quite small and a sufficiently accurate correction made by assuming that the residual die-away is logarithmic with a value either determined experimentally or calculated from the known volume of ventilating air. If $C_{1}$ parts per million of tracer gas were present at the start of the sample and $C_{2}$ at the end then the correction to be added in order to arrive at the figure for total exposure to contamination is $60\left(C_{1}-C_{2}\right) / R$ parts per million $\times$ minutes where $R$ is the die-away rate in equivalent air changes per hour. The total figure is then divided by the volume of nitrous oxide liberated, $v$ litres, in order to arrive at the values for exposure to contamination used as a comparative measure, i.e. $\left(\bar{c} t+60\left(C_{1}-C_{2}\right) / R\right) / v$ parts per million $\times$ minutes per litre. The figures for exposure to contamination thus obtained can be compared with those which would have been found if the air in the room had been at all times perfectly mixed. If $V$ is the volume of ventilating air in cubic feet per minute then the calculated exposure to contamination, in parts per million $\times$ minutes per litre, is approximately given by $35,300 / V$.

The die-away rates, $R$ above, were estimated by plotting the logarithm of the gas concentration $c$ remaining at a given time against the time $t$ drawing the best straight line by eye through the linear portion of the curve and evaluating $R$ from the relation

$$
R \bumpeq 138\left(\log C_{1}-\log C_{2}\right) /\left(t_{2}-t_{1}\right),
$$

where $R$ is given in equivalent air changes per hour, when $t$ is expressed in minutes. When the air movement in the room was so low that, owing to inadequate mixing, no satisfactory exponential die-away was observed following the standard liberation experiments, die-away rates were measured while the air was being vigorously mixed by a large fan. The values of the die-away rate obtained in this way were used to estimate the volume of ventilating air passing through the room on those occasions when direct measurement of the air volume was difficult or unreliable.

A complete set of measurements in any one theatre normally involved eight liberation experiments, each of which occupied about $20 \mathrm{~min}$., so that the whole series could be completed, including the setting up of the apparatus, in about $4 \mathrm{hr}$.

In addition to the gas tracer measurements a number of other observations were regularly made:

(a) Measurements of the velocity of air movement through the ventilating inlets and outlets and through any other openings. 
(b) Observations of air movement, especially around doors and windows, using smoke from titanium tetrachloride.

(c) Measurement of pressure difference between the air of the theatre and the outside.

(d) Measurements of air velocity across the operating-table, using the silvered high temperature kata thermometer.

(e) Inlet and room air temperatures and relative humidities.

$(f)$ Estimation of radiation temperature with the globe thermometer.

In a number of experiments an attempt was made to see whether the presence of persons closely clustered around the operating-table affected the results. Five or six dummies some $5 \mathrm{ft} .6 \mathrm{in}$. high and about $18 \mathrm{in}$. diameter constructed of polythene bags draped over light frames were placed around the table. No substantial or systematic difference between measurements made with these dummies present or absent was detected and this aspect of the investigation is not discussed further. In other experiments, particularly those carried out in the theatres fitted with a downward displacement type of ventilation, some investigations of the effect of movement of persons in the theatre were made. As a standard procedure one of the investigators walked briskly round the room at a distance of about 6-8 ft. from the table throughout a measurement.

\section{RESULTS}

Thirty-two visits were made to a total of twenty-six operating-theatres; all but two of these were provided with mechanical ventilation. In five, including two dummy experimental theatres, the ventilation plant was designed to provide pistontype downward displacement ventilation as advocated by Bourdillon \& Colebrook (1946) and more recently by Blowers \& Crew (1960). In the remainder the air was more or less turbulently mixed but with very differing degrees of air movement.

The results of the measurements in the turbulent mixing theatres are summarized in Table 1 and those for the downward displacement theatres in Table 2. In Figs. 2 and 3 the performance of the different ventilation systems is compared by means of a performance index, the ratio of the observed figure for exposure to contamination to the figure calculated for the actual volume of ventilating air on the assumption of perfect mixing. The index thus measures the advantage or disadvantage, the lower the numerical value the better, that a particular system has in comparison with complete mixing in protecting the operation site from contamination. In Fig. 2 the performance index for the turbulent mixing theatres is plotted against the velocity of air movement across the table. This quantity serves as an approximate measure of the degree to which mixing is maintained in the air of the theatre. In Fig. 3 the performance index for the downward displacement theatres is plotted against the difference in temperature between the incoming air and the room air at operating-table level since the efficiency of the piston effect depends very largely on this temperature difference. The velocity of air movement in these theatres was necessarily always small and lay within a comparatively narrow range. 
Table 1. Performance of the ventilating system in a series of operating theatres

\begin{tabular}{|c|c|c|c|c|c|c|c|c|c|}
\hline \multirow{2}{*}{$\begin{array}{l}\text { Visit } \\
\text { no. }\end{array}$} & \multirow{2}{*}{$\begin{array}{l}\text { Volume } \\
\text { of } \\
\text { venti- } \\
\text { lating } \\
\text { air, } \\
\text { cu.ft./ } \\
\text { min. }\end{array}$} & \multirow{2}{*}{$\begin{array}{c}\text { Pressure } \\
\text { difference } \\
\text { to outside, } \\
\text { inches of } \\
\text { water }\end{array}$} & \multirow{2}{*}{$\begin{array}{l}* \text { Direction } \\
\text { of air flow, } \\
\text { In = into the } \\
\text { theatre }\end{array}$} & \multirow{2}{*}{$\begin{array}{c}\text { Air } \\
\text { move- } \\
\text { ment } \\
\text { over } \\
\text { table, } \\
\text { ft./ } \\
\text { min. }\end{array}$} & \multicolumn{5}{|c|}{$\begin{array}{c}\text { 'Exposure to contamination', } \\
\text { parts per million } \times \text { minutes } \\
\text { per litre }\end{array}$} \\
\hline & & & & & 1 & 2 & 3 & 4 & 5 \\
\hline 1 & 250 & -0.04 & In & 20 & 94 & 180 & 109 & - & 141 \\
\hline 2 & 480 & +0.2 & Out & 72 & 71 & 131 & 71 & - & 74 \\
\hline 3 & 600 & Very small & - & 20 & 64 & 67 & 52 & 61 & 59 \\
\hline 4 & 640 & $+0 \cdot 2$ & Out & 15 & 112 & 530 & 80 & - & 55 \\
\hline 5 & 650 & -0.02 & In & $50 \dagger$ & 66 & 53 & 72 & - & 54 \\
\hline 6 & 665 & +0.01 & Out & 10 & 116 & 154 & 68 & 51 & 53 \\
\hline 7 & 690 & Very small & In/Out & 6 & 163 & 466 & 24 & - & 51 \\
\hline 8 & 695 & Very small & In/Out & 15 & 65 & 126 & 58 & 60 & 51 \\
\hline 9 & 750 & Very small & In/Out & 15 & 93 & 250 & 63 & - & 47 \\
\hline 10 & 800 & Very small & - & 35 & 58 & 34 & 35 & 61 & 44 \\
\hline 11 & 830 & -0.03 & In & 8 & 74 & 150 & 48 & - & 43 \\
\hline 12 & 865 & +0.01 & Out & 30 & 54 & 104 & 34 & - & 41 \\
\hline 13 & 940 & +0.4 & Out & 105 & 34 & 43 & 49 & - & 38 \\
\hline 14 & 970 & +0.09 & Out & 25 & 54 & 132 & 80 & - & 36 \\
\hline 15 & 1000 & Very small & In & 20 & 48 & 103 & 41 & - & 35 \\
\hline 16 & 1050 & Very small & Out & 15 & 111 & 226 & 28 & 33 & 34 \\
\hline 17 & 1125 & -0.03 & In & 16 & 45 & 96 & 12 & - & 30 \\
\hline 18 & 1200 & Very small & Out & $(100)$ & - & 35 & 27 & 31 & 29 \\
\hline 19 & 1200 & Very small & Out & 120 & 38 & 34 & 36 & 27 & 29 \\
\hline 20 & 1280 & $+0 \cdot 04$ & Out & 20 & 32 & 40 & 40 & - & 28 \\
\hline 21 & 2100 & -0.01 & In & 7 & 16 & 58 & 49 & 20 & 16 \\
\hline 22 & 2300 & +0.01 & Out & 40 & 36 & 25 & 19 & - & 15 \\
\hline 23 & 2700 & - & Out & 200 & 16 & 16 & 9 & - & 13 \\
\hline 24 & 2700 & - & Out & 150 & 24 & 13 & 10 & 24 & 13 \\
\hline
\end{tabular}

The blank spaces signify that no observation or measurement was made.

Nos. 2 and 13 refer to the same theatre with different settings of the ventilation plant controls.

Nos. 11 and 17 refer to the two halves of a twin suite.

Nos. 18 and 19 refer to different visits to the same theatre.

No. 22 relates to the same theatre as no. 1 after this had been partly rebuilt and a ventilating plant installed.

Nos. 23 and 24 refer to different visits to the same theatre.

The several columns headed 'exposure to contamination' refer:

1. To experiments when the tracer was liberated $5 \mathrm{ft}$. above floor level.

2. To experiments when the tracer was liberated $3 \mathrm{ft}$. above floor level.

3. To experiments when the tracer was liberated $1 \mathrm{ft}$. 6 in. above floor level.

4. To experiments when the tracer was liberated at the side of the room.

5. To the value calculated for complete air mixing within the theatre.

* Direction of air flow between the theatre and adjacent passages, etc.; either through the gaps around the edges of the entry doors or through the door openings. In-indicates flow into the theatre, Out-indicates flow out from the theatre and In/Out-indicates that the air movements observed were either variable or in opposite directions across different parts of the aperture.

$\dagger$ This velocity varied from near zero up to $100 \mathrm{ft}$./min. according to the operation of the heating plant. 
Table 2. Performance of downward displacement ventilating systems

\begin{tabular}{|c|c|c|c|c|c|c|c|c|c|c|}
\hline \multirow{2}{*}{$\begin{array}{l}\text { Theatre } \\
\text { no. }\end{array}$} & \multirow{2}{*}{$\begin{array}{l}\text { Volume } \\
\text { of } \\
\text { venti- } \\
\text { lating } \\
\text { air, } \\
\text { cu.ft./ } \\
\text { min. }\end{array}$} & \multirow{2}{*}{$\begin{array}{c}\text { Air } \\
\text { move- } \\
\text { ment } \\
\text { over } \\
\text { table, } \\
\text { ft./ } \\
\text { min. }\end{array}$} & \multirow{2}{*}{$\begin{array}{c}\text { Level } \\
\text { of } \\
\text { activity }\end{array}$} & \multirow{2}{*}{$\begin{array}{l}\text { Tem- } \\
\text { perature } \\
\text { differ- } \\
\text { ential } \\
\left({ }^{\circ} \mathrm{F} .\right)\end{array}$} & \multicolumn{6}{|c|}{$\begin{array}{l}\text { 'Exposure to contamination', } \\
\text { parts per million } \times \text { minutes per litre }\end{array}$} \\
\hline & & & & & 1 & 2 & 3 & 4 & 5 & 6 \\
\hline 1 & 1100 & 20 & $\begin{array}{l}\mathbf{Q Q} \\
\mathbf{Q} \\
\mathbf{C W}\end{array}$ & $\begin{array}{l}+1 \\
+1 \\
+1\end{array}$ & $\begin{array}{l}48 \\
60 \\
42\end{array}$ & $\begin{array}{l}\overline{31} \\
34\end{array}$ & $\begin{array}{r}<2 \\
8 \\
20\end{array}$ & $\begin{array}{l}21 \\
-\end{array}$ & - & $\begin{array}{l}32 \\
32 \\
32\end{array}$ \\
\hline 1 & 1000 & 25 & $\begin{array}{l}\mathbf{Q} \\
\mathbf{C W}\end{array}$ & $\begin{array}{l}+2 \\
+2\end{array}$ & 65 & $>200$ & $\begin{array}{r}8 \\
24\end{array}$ & - & - & $\begin{array}{l}35 \\
35\end{array}$ \\
\hline 2 & 925 & 10 & $\begin{array}{l}\mathbf{Q} \\
\mathbf{C W} \\
\mathbf{Q}\end{array}$ & $\begin{array}{l}+6 \\
+6 \\
-3\end{array}$ & $\begin{array}{l}80 \\
42 \\
-\end{array}$ & $\begin{array}{l}18 \\
45 \\
73\end{array}$ & $\begin{array}{r}6 \\
28 \\
-\end{array}$ & $\begin{array}{l}47 \\
-\end{array}$ & $\begin{array}{l}20 \\
24 \\
22\end{array}$ & $\begin{array}{l}38 \\
38 \\
38\end{array}$ \\
\hline 2 & 900 & 10 & $\begin{array}{l}\mathbf{Q} \\
\mathbf{C W} \\
\mathbf{Q}\end{array}$ & $\begin{array}{r}+5 \\
+5 \\
>+6\end{array}$ & $\begin{array}{r}151 \\
56 \\
-\end{array}$ & $\begin{array}{r}137 \\
117 \\
18\end{array}$ & $\begin{array}{l}2 \frac{1}{2} \\
-\end{array}$ & $\begin{array}{l}62 \\
- \\
-\end{array}$ & $\begin{array}{r}7 \\
-\end{array}$ & $\begin{array}{l}39 \\
39 \\
39\end{array}$ \\
\hline 3 & 930 & 14 & $\begin{array}{l}\mathbf{Q} \\
\mathbf{Q} \\
\mathbf{C W}\end{array}$ & $\begin{array}{r}+2 \\
+9 \\
+9\end{array}$ & $\begin{array}{r}30 \\
112 \\
58\end{array}$ & $\begin{array}{l}- \\
20 \\
-\end{array}$ & $\begin{array}{l}-\overline{1} \\
<\frac{1}{2} \\
31\end{array}$ & $\begin{array}{l}- \\
-\end{array}$ & - & $\begin{array}{l}38 \\
38 \\
38\end{array}$ \\
\hline 4 & 1200 & - & $\begin{array}{l}\text { Q } \\
\text { CW } \\
\text { Q } \\
\text { CW }\end{array}$ & $\begin{array}{l}+2 \\
+2 \\
-2 \\
-2\end{array}$ & $\frac{-}{-}$ & $\begin{array}{r}31 \\
41 \\
91 \\
120\end{array}$ & $\begin{array}{l}- \\
-\end{array}$ & $\begin{array}{l}- \\
-\end{array}$ & $\begin{array}{l}- \\
-\end{array}$ & $\begin{array}{l}39 \\
29 \\
29 \\
29\end{array}$ \\
\hline $4 \mathrm{H}$ & 1200 & - & $\begin{array}{l}\mathbf{Q} \\
\text { CW } \\
\mathbf{Q} \\
\text { CW }\end{array}$ & $\begin{array}{l}+1 \\
+1 \\
-\frac{1}{2} \\
-\frac{1}{2}\end{array}$ & $\begin{array}{l}- \\
-\end{array}$ & $\begin{array}{r}<\frac{1}{2} \\
16 \\
72 \\
21\end{array}$ & $\begin{array}{l}- \\
- \\
-\end{array}$ & $\begin{array}{l}- \\
- \\
-\end{array}$ & $\begin{array}{l}- \\
-\end{array}$ & $\begin{array}{l}29 \\
29 \\
29 \\
29\end{array}$ \\
\hline $5 \mathrm{H}$ & 1300 & - & $\begin{array}{l}\text { Q } \\
\text { CW } \\
\text { Q } \\
\text { CW }\end{array}$ & $\begin{array}{l}+\frac{1}{2} \\
+1 \\
-1 \\
-1\end{array}$ & $\begin{array}{l}- \\
- \\
-\end{array}$ & $\begin{array}{r}<\frac{1}{2} \\
8 \\
72 \\
86\end{array}$ & $\begin{array}{l}- \\
- \\
-\end{array}$ & $\begin{array}{l}- \\
-\end{array}$ & $\begin{array}{l}- \\
-\end{array}$ & $\begin{array}{l}27 \\
27 \\
27 \\
27\end{array}$ \\
\hline
\end{tabular}

The blank spaces signify that no observation or measurement was made.

Nos. 4 and 5 were the two dummy operating-theatres. The suffix $H$ indicates those experiments where a porous false ceiling of hessian was fitted.

Level of activity. QQ absolutely still, $Q$ very little movement, $C W$ one person walking continuously round the room.

Temperature differential. The difference between the temperature of the ventilating air and that at the centre of the room $3 \mathrm{ft}$. above the floor.

The several columns headed 'exposure to contamination' refer:

1. To experiments when the tracer was liberated $5 \mathrm{ft}$. above floor level.

2. To experiments when the tracer was liberated $3 \mathrm{ft}$. above floor level.

3. To experiments when the tracer was liberated $1 \mathrm{ft}$. $6 \mathrm{in}$. above floor level.

4. To experiments when the tracer was liberated $5 \mathrm{ft}$. above floor level at the side of the room.

5. To experiments when the tracer was liberated $1 \mathrm{ft} .6$ in. above floor level at the side of the room.

6. To the value calculated for complete air mixing within the theatre. 


\section{Turbulent mixing ventilation systems}

Except for two theatres ( 1 and 7 ) which were not provided with mechanical ventilation, all these theatres were ventilated by a positive input through inlets placed at high level. Out of the nineteen such theatres, however, four $(5,11,17$

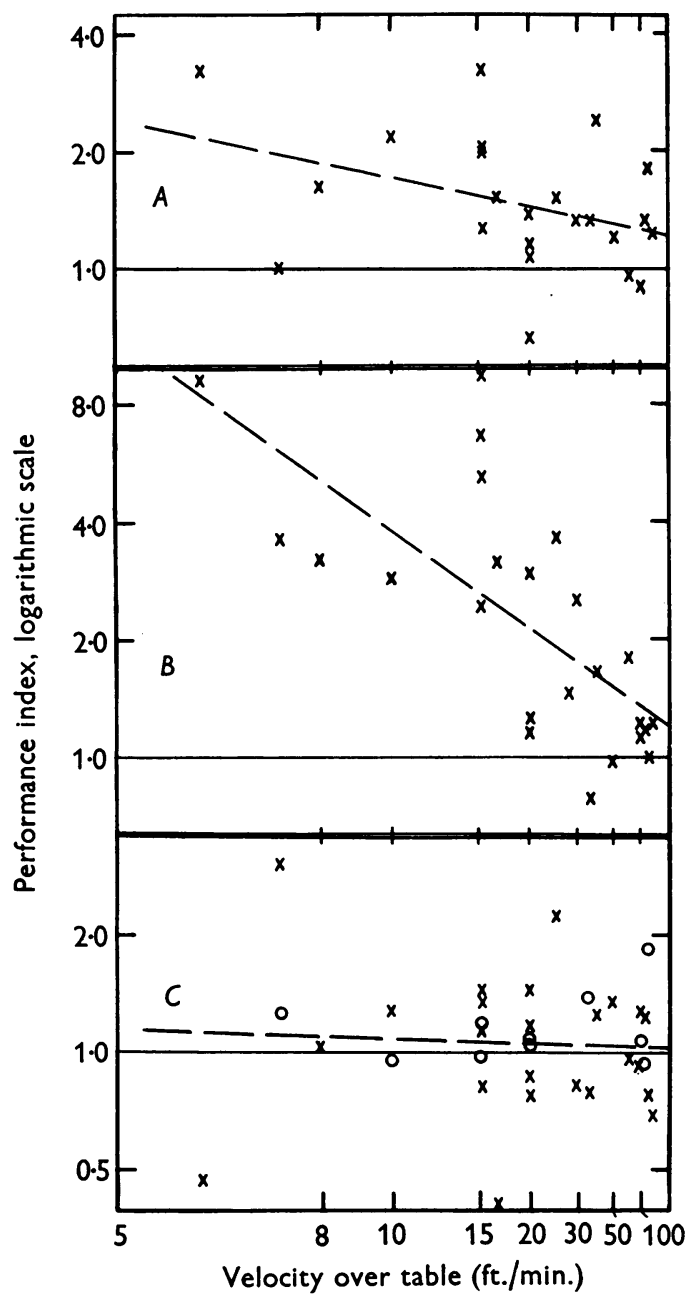

Fig. 2. Performance of turbulent mixing ventilation systems. A. Tracer liberated at $5 \mathrm{ft}$. above the floor. B. Tracer liberated at $3 \mathrm{ft}$. above the floor. C. Tracer liberated at $1 \mathrm{ft} .6 \mathrm{in}$. above the floor, crosses, or at the side of the room, circles. The interrupted lines are the calculated regression lines for performance index on air velocity. (On diagram $\mathrm{C}$ this refers to the data for liberation at $1 \mathrm{ft} .6 \mathrm{in}$. above the floor, crosses, only.) The air velocity is plotted on a reciprocal scale reading to the left from the right-hand edge of the figure as zero, i.e. the right-hand edge corresponds to an infinitely large velocity.

and 21) were at a measurable negative air-pressure with respect to the rest of the hospital; one more, 15, showed a well-defined air flow into the theatre from outside although the pressure difference was not measurable and in two more ( 8 and 9$)$ the 


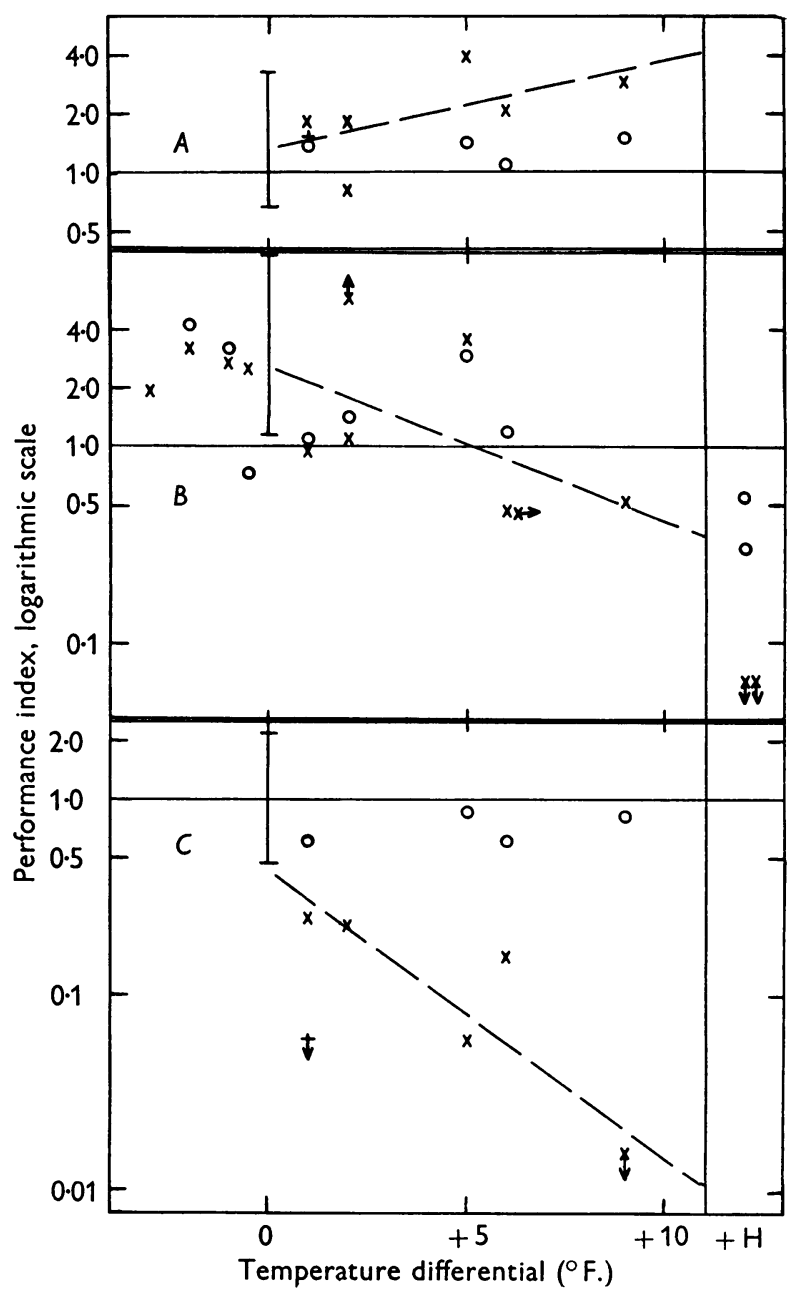

Fig. 3. Performance of downward displacement ventilation systems. A. Tracer liberated at $5 \mathrm{ft}$. above the floor. B. Tracer liberated at $3 \mathrm{ft}$. above the floor. C. Tracer liberated at $1 \mathrm{ft} .6 \mathrm{in}$. above the floor. Latin crosses, absolutely no movement in the theatre. St Andrew's crosses, very little movement in the theatre. Circles, one person continuously walking round in the theatre. An arrow attached to any symbol indicates that there was some uncertainty in the estimate such that the true value was probably displaced from that shown on the diagram in the sense indicated by the arrow. The region at the right-hand edge of the figure labelled $+\mathrm{H}$ includes data obtained with a positive temperature differential under a hessian screen suspended below the ceiling. The vertical lines at zero temperature differential show the range of values of the performance index observed in those turbulent mixing systems which had similar air movement velocities to those found in the downward displacement systems, i.e. not exceeding $25 \mathrm{ft}$./min. over the operating-table. The interrupted lines are the calculated regression lines for performance index on temperature differential with quiet conditions in the theatre, i.e. they refer to the data indicated by the St Andrew's crosses only. 
air flow observed was fluctuating. In only four $(2,4,14$ and 20$)$ was the theatre, with its doors shut, at a substantial positive pressure to the outside. One more theatre (23 and 24) should probably be added to these although pressure measurements were not actually carried out. In the remaining seven theatres although the air flow when examined was outwards from the theatre through the gaps around the closed doors the pressure difference maintaining this flow was very small and would, therefore, be easily reversed by unfavourable wind conditions or by door movements in or near the theatre suite.

Temperatures, particularly in view of the low velocities of air movement commonly encountered, were usually higher than those accepted as comfortable even for persons engaged in only very light activity (Bedford, 1948). The median value of the dry bulb temperature was $74^{\circ} \mathrm{F}$. The readings of the globe thermometer, which is sensitive to the radiant temperature of the walls, were, except in one case (No. 9, Table 1), within $\pm 2^{\circ} \mathrm{F}$. of the air temperature; as the relative humidities were rarely as high as $60 \%$ the dry bulb temperatures themselves are a good index of working comfort as far as the thermal conditions are concerned.

The figures given in Table 1 show clearly that the observed values of 'exposure to contamination' for all positions at which the tracer gas was liberated were closely, and approximately inversely, related to the actual volume of ventilating air supplied. There are, however, substantial divergencies from this simple relationship which can be more easily examined in terms of the values of the performance index, which allows for the differences in the volume of ventilating air.

The values for the performance index given in Fig. 2 show that low velocities of air movement across the table are associated with high values of this index when the contaminant is liberated above and around or, especially, close to and around the operating site. This is easily explicable in terms of the tendency of the local cloud in these circumstances to remain in the vicinity of the place where it is produced. The regression lines included in the figure are consistent, within the limits of their error, with the expectation that the performance index should approximate to unity as the air velocity at the centre of the room becomes large. Contamination produced close to the floor or remote from the table usually leads to an exposure to contamination only slightly different from that associated with perfect mixing and is little affected by the amount of air movement present.

It has been suggested that increased air velocities over the table might result in increased risk of deposition into the wound of airborne material. It seemed desirable to explore this possibility, especially in view of the advantage of moderately high air velocities indicated above. In a series of laboratory tests room air was blown by a fan across a series of open Petri dishes placed at varying distances behind and in front of the fan so that the air velocities over the dishes ranged from about 20 to about $300 \mathrm{ft}$./min.

Air was also drawn over a series of Petri dishes and other collecting surfaces in a wind tunnel. The tunnel could be placed either horizontally or vertically so that the direction of air flow was vertically downwards on to the exposed collecting surfaces. The air flow was substantially laminar in these experiments.

During a number of the experiments in the operating theatres a series of air 
samples were taken in the size-grading sampler (Lidwell, 1959) and simultaneously by sedimentation on to open Petri dishes placed on the operating-tables. From the size distribution of the airborne bacteria calculated from the samples obtained in the size-grading sampler it was possible to deduce the numbers which would have been expected to settle on to the exposed Petri dishes. Any excess deposition in those theatres with higher air velocities might be attributed to an impingement effect.

The wind tunnel experiments showed no significant differences in the rates of deposition either on to the Petri dishes or on to the other collecting surfaces at air speeds between 20 and $200 \mathrm{ft}$./min. whether the direction of air flow was vertical or horizontal.

Table 3. Sedimentation at various velocities of air movement

$\begin{array}{ccc}\text { Theatre } & \text { Velocity } & \text { Observed numbers settling } \\ \text { no. } & \text { ft./min. } & \text { Expected numbers } \\ 20 & 10 & 0 \cdot 90 \\ 14 & 15 & 0 \cdot 78 \\ 19 & 15 & 1 \cdot 14 \\ 22 & 15 & 0 \cdot 84 \\ 17 & 20 & 1 \cdot 20 \\ 18 & 35 & 0 \cdot 92 \\ 8 & 120 & 1 \cdot 01 \\ 7 & 150 & 1 \cdot 43 \\ 7 & 150 & 1 \cdot 06 \\ \text { Laboratory } & 25 & {[1 \cdot 0]} \\ \text { Laboratory } & 60 & 0 \cdot 97 \\ \text { Laboratory } & 125 & 1 \cdot 36 \\ \text { Laboratory } & 155 & 1 \cdot 60 \\ \text { Laboratory } & 300 & 3 \cdot 16\end{array}$

The results of the experiments using the fan to blow the air directly over the Petri dishes are given in Table 3. These show a small increase in deposition, of about $30 \%$, at linear velocities of $100 \mathrm{ft}$./min., increasing at higher velocities. The air flow in this situation will include many small vortices originating at the edges of the fan blades and it is presumably these which are reponsible for the increased deposition close to the fan. The experiments carried out in the operating-theatres themselves, also included in Table 3, show little if any effect on sedimentation of velocities up to $150 \mathrm{ft}$. $/ \mathrm{min}$.

It would therefore seem that no disadvantage, in terms of increased impingement into the wound, is likely with air velocities of the order of $50 \mathrm{ft}$./min. over the table. Air velocities of this magnitude appear from the data exhibited in Fig. 2 and Table 1 to be sufficient to ensure most of the benefit obtainable from good air mixing while velocities over $100 \mathrm{ft}$./min. which might possibly lead to a risk of increased deposition into the wound would usually be found uncomfortable.

\section{Downward displacement ventilating systems}

All the downward displacement theatres were so arranged as to be at an adequate positive pressure to their surroundings. The temperature and humidity conditions were not of interest since these were adjusted for the purposes of the observations. 
The values for the performance index given in Fig. 3 show that for the downward displacement systems the performance of the ventilating system is complex.

Contamination liberated, at any position, just above floor level is removed very effectively if a good displacement piston is established by a substantial temperature differential. In contrast, liberation at the 5 - $\mathrm{ft}$. level produces figures for exposure to contamination which are greater than those calculated for complete mixing and show some tendency to become greater the more effective the piston action, at least within the range of temperature differentials covered by our experiments. The same is to some extent true for liberation at the 5 -ft level remote from the operating table. With liberation at the 3 -ft. level the magnitude of the temperature differential is critical. If this is high enough the piston effect is sufficiently well defined to carry the contamination downwards with a low exposure to contamination at the sampling point. But if the temperature differential is only small a high exposure to contamination results, similar to that found in a turbulently mixed theatre with comparably slow rates of air movement.

Since the operation of a displacement system depends on the maintenance of horizontal stratification and minimal vertical turbulence it seemed necessary to examine the effects of movement of persons in the theatre. The amount of movement to be expected in an operating-theatre is not easy to define and will, in any case, vary considerably. The standard amount of movement adopted for these tests, one person walking steadily round the room throughout the experiment, was thought to be perhaps rather more, but not excessively more, than that which might occur reasonably often in practice. The effect of movement is, as would be expected, to bring the values for exposure to contamination closer to those calculated for complete mixing, that is to reduce or destroy the downward displacement effect. This is particularly noticeable for those experiments in which the contamination was liberated just above floor level. The striking effectiveness of this system under these conditions largely disappears with our standard amount of movement.

In the two dummy theatres some observations were made with the ventilating air being introduced through a porous ceiling, in this case of hessian, suspended below the true ceiling. Under these conditions the residual turbulence was very low. Due to this, it was not possible to maintain more than a very small, $\frac{1}{2}-1^{\circ} \mathrm{F}$., temperature differential between the incoming air and the air temperature at table level. The stabilization of air flow was, however, so much improved that figures for exposure to contamination for liberation at the $3 \mathrm{ft}$. level (measurements were not made with liberation at the $5 \mathrm{ft}$. or $1 \mathrm{ft} .6 \mathrm{in}$. levels) were considerably lower than those obtained with differentials of $6-8^{\circ} \mathrm{F}$. using Airmaster inlets in the ceiling.

\section{Twin theatre suites}

The limited number of occasions when the tracer was liberated in one theatre of a twin suite and the tracer concentration was estimated in the other showed clearly the extent of the air exchange between such pairs of theatres. On an average the exposure to contamination under these conditions was as much as 
1/6th of that found when liberation took place in the theatre being examined. In each case the theatres were linked by a common sterilizing room without separating doors, as well as by other means, and it was apparent from smoke tests that the thermal circulation generated in the sterilizer rooms produced considerable air exchange between them and the theatres in spite of the exhaust fans installed over the sterilizers. In addition, when the theatres were maintained at a positive pressure to the lobby, opening the door into one theatre caused the greater part of the ventilating air of the other theatre to pass out through any linking rooms and the first theatre.

\section{DISCUSSION}

The observations on the effectiveness of the ventilating systems reported in this paper have throughout been carried out using a gaseous tracer. A particulate cloud, for example, an artificially produced cloud of bacteria-carrying particles, would clearly be a closer model for the behaviour of naturally produced bacterial contamination of the air. There are, however, disadvantages in introducing such material, however apparently innocuous, into operating theatres which are in current use and the difficulties of obtaining reproducible liberation and rapid measurement are enormously greater than with a gaseous tracer. The median equivalent particle diameter for airborne staphylococci found in ward air (Lidwell, Noble \& Dolphin, 1959) appears to be between 12 and $15 \mu$. Particles of this size have a settling rate of only about $1 \mathrm{ft}$./min. Turbulent air movements, even in very quiet rooms, are usually ten times this velocity or more. The movements of the airborne particles around the room will, therefore, usually follow the actual air movements very closely, so that the observed variations in the concentration of the gaseous tracer will approximate to the changes in concentration of an airborne bacterial contaminant and give a good estimate of the relative risk of bacterial sedimentation at the sampling point. This rate of settling is, however, sufficient to contribute significantly to the rate of clearance of such particulate matter from the room air; in rooms of about 10-12 ft. high it will be equivalent to five or six air changes per hour. Measurements made with a gaseous tracer will, therefore, underestimate by this amount the clearance rate for bacteria likely to be found in practice.

Our observations were confined to contamination reaching the centre of the operating-table. Instruments and dressings laid out on trolleys are also exposed to the risk of airborne contamination. We have no direct estimate of this, but it is likely to be of a similar order to that found at the operating-table.

The main purpose of the investigation was an attempt to ascertain which ventilating system or systems were most apt to protect the wound from extraneous airborne contamination.

With ventilation systems other than the downward displacement type it seems desirable that there should be a reasonable degree of air movement in the theatre to avoid the persistence of local clouds of contamination. Adequate mixing is obtained with air velocities over the operating-table of $40-50 \mathrm{ft} . / \mathrm{min}$. and at this 
velocity there does not appear to be any risk of increased impingement into the wound due to the air movement.

We have no absolute standards for the permissible levels of contamination so that it is not possible to do more than suggest the desirable volume of ventilation to be supplied. As the contamination levels are dependent on the volume of air supplied, and not on the rate of air change, any specification should be in this form, and as a round figure in line with good present day practice and adequate to maintain a positive pressure within the theatre $1000 \mathrm{cu}$. ft. a minute of clean filtered air supplied to the theatre itself might be taken as a working basis for a normal theatre.

The downward displacement systems are capable of extremely effective removal of contamination from the theatre where this is liberated at low level. Before this

\section{Table 4. Performance indices of turbulent mixing and of downward displacement ventilating systems}

\begin{tabular}{|c|c|c|c|c|c|c|}
\hline \multirow{2}{*}{$\begin{array}{l}\text { Level at which } \\
\text { contamination is } \\
\text { liberated }\end{array}$} & \multicolumn{3}{|c|}{$\begin{array}{l}\text { Turbulent mixing systems: } \\
\text { air velocity over table }\end{array}$} & \multicolumn{3}{|c|}{$\begin{array}{c}\text { Downward displacement } \\
\text { systems: temperature } \\
\text { differential and level } \\
\text { of activity }\end{array}$} \\
\hline & $\begin{array}{l}\text { Very } \\
\text { high }\end{array}$ & $\begin{array}{l}40-50 \\
\text { f.p.m. }\end{array}$ & $\begin{array}{l}\text { Up to } \\
25 \text { f.p.m. }\end{array}$ & $+5^{\circ} \mathrm{F}$. & $\begin{array}{c}0^{\circ} \mathrm{F} . \\
\mathrm{Q}\end{array}$ & $\begin{array}{l}+5^{\circ} \mathrm{F} \\
\mathrm{CW}\end{array}$ \\
\hline $5 \mathrm{ft}$. above floor & $1 \cdot 2$ & $1 \cdot 3$ & $1 \cdot 5$ & $2 \cdot 2$ & $1 \cdot 3$ & $1 \cdot 3$ \\
\hline $3 \mathrm{ft}$. above floor & $1 \cdot 2$ & 1.5 & $3 \cdot 2$ & $1 \cdot 0$ & $2 \cdot 5$ & $1 \cdot 4$ \\
\hline $1 \mathrm{ft} .6$ in. above floor & $1 \cdot 0$ & $1 \cdot 0$ & $1 \cdot 1$ & 0.08 & 0.5 & $0 \cdot 7$ \\
\hline
\end{tabular}

The values given in this table have been taken from data and from the regression lines shown in Figs. 2 and 3; they represent therefore predicted performance figures. Actual observed indices might be expected to show considerable variation about these values.

The values give the relative exposures to contamination in various circumstances for the same volume of ventilating air. If this volume is altered for any conditions then the relative exposure to contamination for the changed ventilation value is given by dividing the index given in the table for this condition by the proportionate change in the volume of ventilating air, e.g. if the volume of air supplied is to be doubled then the index given must be halved.

The air velocities are those estimated from kata thermometer readings and are given in feet per minute.

Temperature differential. The difference between the temperature of the ventilating air and that at the centre of the room $3 \mathrm{ft}$. above the floor.

The levels of activity are given as in Table $2: \mathrm{Q}$ very little movement in the room, $\mathrm{CW}$ one person walking continuously round the room.

advantage can be accepted as useful it will be necessary to ascertain whether the more dangerous sources of airborne contamination liberate the infective material at high or low level. It will also be necessary to find out how far the ordinary movements of the theatre staff disturb the piston effect during operations. A downward displacement system which is not operating effectively is, by virtue of the low values of air movement necessarily associated with it, liable to result in high values of exposure to contamination from the persistence of local clouds around the table.

The performance of the two types of ventilation systems discussed in this paper is compared in Table 4. In interpreting the figures given in this table it should be 
remembered that the values relate to exposure to contamination so that the smaller the numerical value the more effective is the ventilation system and that a value of unity corresponds to complete mixing of the air of the room at all times, i.e. any contamination is at all times uniformly distributed throughout the whole volume of the room. The value of moderate air velocities in preventing high exposure when the contamination is introduced close to and on a level with the operating table in a turbulent mixing system is obvious as is the appearance of this risk in a downward displacement system when for any reason a sufficient differential cannot be maintained between the incoming air temperature and the general air temperature of the room.

Our visits to these operating-theatres have also brought to our attention a large number of points connected with their heating and ventilating. Some of these are of general concern.

A frequent complaint from the staffs was that the theatres were usually too hot and were unbearably so during warm weather. This was often coupled with a demand for cooling equipment. Under almost all conditions, however, the ambient outdoor temperature would be sufficiently low to be acceptable and the trouble arose from the amount of wild heat fed into the theatre suite from autoclaves and the steam pipes serving them. This was often aggravated by the inconvenient and lengthy procedure necessary to effect changes in the settings of the various controlling elements in the system. Such absurdities as running the steam pipes in the same channels as the air ducts (in one case this by itself produced a rise of $10-12^{\circ} \mathrm{F}$. in the air temperature), control valves only accessible by removing panels and crawling into under-floor trenches, have come to our notice in the course of the study. But a more serious problem is the thermal isolation of the autoclaves. Usually these are enclosed in a hollow space in one of the walls and, while some insulation is provided, the operating panel, many tens of square feet in area, is frequently too hot to be touched comfortably, so that although the nuisance from steam, condensation, or excessive humidity, is largely avoided by the change from boiling water sterilizers to autoclaves the problem of excessive heat dissipation still remains. Apart from improved lagging and reduction of the panel area by placing recording instruments on adjacent walls, ventilation of the within wall space would seem to be the easiest way of reducing the heat transfer into the operating-suite. These are primarily engineering problems and there seems no reason why they should not be satisfactorily solved so that effective and direct control of the thermal conditions within the operating-theatre can be put in the hands of the theatre staff.

On bacteriological grounds twin theatre suites with intercommunicating sterilizing and other auxiliary rooms must be regarded as a risk. The extent to which the two theatres share a common atmosphere when there are no doors between them and their common service rooms is perhaps surprising. This is largely a consequence of the thermal circulations set up by the wild heat liberated in the sterilizing-room. While better thermal isolation of the autoclave should reduce this it is unlikely to eliminate it entirely. It is possible that appropriate arrangements of the ventilating system with air curtains across the aperture could reduce the volume of air 
transfer to a satisfactorily low level but the installation would need to be complex and the curtains would probably not be maintained when the doors to either theatre were opened so that the pressure in that theatre was suddenly reduced. The provision of doors between the theatres and any rooms linking the two theatres of a twin suite seems likely to be much the most reliable method of limiting air exchange between them.

It is disturbing to find how often theatres which are nominally provided with a positive pressure ventilation system in order to exclude air from outside are, in fact, doubtfully so isolated or even are actively drawing in air from the rest of the hospital. This situation seems to arise from an overconfidence on the part of the designers that if an input is provided rated at $120 \%$ or so of the extract then the difference between the two is sufficient to maintain the positive pressure required and will persist throughout the life of the plant. Both of these assumptions are doubtful. Apart from faulty calculations - and the accurate measurement of air flow is not always very easy-obstruction of grilles and filters may substantially reduce the rated volume of air flow. There are usually more opportunities for such reduction on the input side. In addition the maintenance of air flow in the desired direction in the face of varying wind conditions and thermal circulations, particularly when the doors are open, demands substantial volumes of air. Adequate positive pressures have, in our limited experience, only been found when the mechanical extract was no more than one-third of the actual air input. If the doors to the suite are close fitting it is then necessary to provide some means of exit for the remaining two-thirds of the ventilating air. This is probably best done by providing exhaust ports fitted with weighted flaps which will lift at the design pressure of the theatre but fall back and make the full volume of ventilating air available to provide an outward flow when the doors are opened (Blowers \& Crew, 1960).

In no theatre that we have visited was there any means of knowing whether the ventilating plant was in fact delivering the volume of air that it was supposed to. In fact cases have, to our knowledge, occurred when a complete blockage of the air intake to the plant has gone undetected for a considerable period. There are several ways in which the air delivery could be indicated in the theatre suite. Vanes in the duct operated by the air flow can be connected to signal lights or quantitative indication can be given by the pressure drop across an orifice plate or the readings of a remote indicating anemometer.

\section{SUMMARY}

Measurements to assess the performance of the ventilating system have been carried out in a series of twenty six operating theatres using nitrous oxide as a gaseous tracer to simulate the movement of airborne bacterial contamination. In order to prevent local clouds of contamination derived from the activities of the operating-team persisting in the neighbourhood of the operating-site it is desirable that there should be appreciable air movement in the centre of the room. Downward displacement, 'piston type', ventilation systems may be an exception to this 
but the indications for their use are not clear. Other points discussed include the necessity for the limitation of the volume of mechanical exhaust if adequate positive pressure is to be maintained in the theatre and the need to control heat dissipation from sterilizers, autoclaves and other sources.

Our thanks are due to the officers of the Regional Hospital Boards, to the hospital secretaries, and to the pathologists, engineers and other members of the hospital staffs, whose co-operation made this investigation possible.

\section{REFERENCES}

Bedford, T. (1948). Basic Principles of Ventilation and Heating, pp. 96 and 97, London: H. K. Lewis and Co. Ltd., 1948.

Blowers, R. \& Crew, Beryl (1960). J. Hyg., Camb., 58, 427.

Bourdillon, R. B. \& Colebrook, L. (1946). Lancet, i, 601.

LIDWELl, O. M. (1959). J. Sci. Instrum. 36, 3.

Lidwell, O. M. (1960). J. Hyg., Camb., 58, 297.

Lidwell, O. M., Noble, W. C. \& Dolphin, G. W. (1959). J. Hyg., Camb., 57, 299. 